\title{
EVALUASI KETEPATAN DOSIS DAN KEEFEKTIFAN TERAPI ANTIHIPERTENSI PADA PASIEN RAWAT INAP DI RS ROEMANI MUHAMMADIYAH SEMARANG
}

\author{
Utami Ambarsari ${ }^{1}$, Nova Hasani Furdianti ${ }^{2}$, Dian Oktianti ${ }^{3}$ \\ Program Studi Farmasi, Universitas Ngudi Waluyo, Ungaran \\ Email: utamiambarsari@gmail.com
}

\begin{abstract}
ABSTRAK
Prevalensi hipertensi di Kota Semarang terus meningkat, pada tahun 2017 sendiri terdapat 13.278 kasus baru. Hipertensi merupakan salah satu penyakit degeneratif yang dalam jangka panjang dapat menyebabkan kerusakan organ-organ penting. Salah satu upaya yang dapat dilakukan dalam mencegah keparahan penyakit tersebut adalah memberikan terapi farmakologis yang tepat. DRPs (Drug Related Problems) merupakan suatu kejadian yang tidak diharapkan yang berkaitan dengan terapi dan dapat mempengaruhi keberhasilan terapi. Penelitian ini bertujuan untuk mengevaluasi ketepatan dosis pada pemberian antihipertensi dilihat pada terjadinya DRPs kategori pemilihan dosis dan keefektifan terapinya. Penelitian ini merupakan penelitian deskriptif analitik dengan pendekatan retrospektif dalam pengambilan data rekam medik pasien rawat inap di RS Roemani Muhammadiyah Semarang periode JanuariDesember 2018. Dalam pengambilan sampel digunakan metode porposive sampling. Sampel yang digunakan sebanyak 79 pasien. Analisis data dilakukan berdasarkan DIH 2018 dan JNC VIII. Hasil penelitian menunjukan, terdapat DRPs kategori pemilihan dosis sebanyak 3 kasus yang terjadi pada 2 pasien. DRPs yang terjadi, yaitu frekuensi pemberian berlebih dan dosis berlebih. Keefektifan terapi antihipertensi pada pasien rawat inap RS Roemani Muhammadiyah Semarang adalah sebesar 69,62\%. Ketepatan pemilihan dosis sebesar 97,47\% dan keefektifan terapi antihipertensi berdasarkan tercapainya target terapi sebesar $69,62 \%$.
\end{abstract}

Kata Kunci: Drug Related Problems (DRPs), Pemilihan Dosis, Keefektifan Terapi, Antihipertensi.

\section{ABSTRACT}

\section{Evaluation Of Antihypertensive Dose And Effectiveness In Inpatients At Roemani Muhammadiyah Hospital Semarang}

The prevalency of hypertension in Semarang kept increasing, in 2017 there were 13.278 new cases of hypertension. Hypertension is a generative disease that in long term can cause organ damage. One thing can be made to prevent the severity of disease is giving appropriate pharmacology therapy. DRPs (Drug Related Problems) is an unwanted incident that correlated to the therapy and can affect the success of therapy. The aim of the study is to evaluate the accuracy of dose on antihypertension administration in the accurrence of DRPs dose selection category and the effectiveness of therapy. This study was descriptive analitic study with retrospective data collected from inpatients medical record at Roemani Muhammadiyah Hospital Semarang in January-December 2018. Purposive sampling method was used in this study. Sample consist of 79 patient. Data were analized based on DIH 2018 and JNC

Evaluasi Ketepatan Dosis... (Utami Ambarsari, Nova Hasani Furdianti, Dian Oktianti)

Journal of Holistics and Health Sciences Vol.1, No. 1 Oktober 2019 
VIII. The result showed that there were DRPs dose selection category as much 3 cases that happened in 2 patients. DRPs accurance, over administration frequency 2 cases and dose too high 1 case. The effectiveness of the therapy in inpatients at Roemani Muhammadiyah Hospital Semarang was 69,62\%. The dose selection accuracy is high at $97,47 \%$ and the effectiveness of antihypertension therapy based on the target is at $69,62 \%$.

\section{Keyword: Drug Related Problems (DRPs), Dose Selection, Therapy Effectiveness, Antihypertension.}

\section{PENDAHULUAN}

Prevalensi hipertensi terus bertambah setiap tahunnya. Berdasarkan hasil pengukuran tekanan darah, prevalensi hipertensi pada 2013 di Indonesia sebesar $25,8 \%$ dan meningkat menjadi $34,1 \%$ pada tahun 2018 . Berdasarkan pengukuran yang dilakukan di Jawa Tengah pada tahun 2017, Kota Semarang memiliki 13.278 kasus baru hipertensi (Dinkes, 2017). Salah satu DRP menurut klasifikasi PCNE V 8.03 (2018) adalah dose selection atau pemilihan dosis. Dalam pengobatan Hipertensi ketepatan pemberian dosis dapat mempengaruhi hasil terapi. Pemberian dosis yang tidak tepat dapat menyebabkan terapi tidak maksimal sehingga tidak tercapai keberhasilan terapi atau dapat menyebabkan efek samping yang tidak diharapkan pada pasien (Cipolle et al, 1998).

Berdasarkan hasil penelitian yang dilakukan oleh Tyashapsari dan Zulkarnain (2012) ketepatan pemberian dosis antihipertensi mencapai 95\%. Namun jika dilihat pada presentase Outcome / tercapainya target terapi, hanya $50 \%$ pasien yang tercapai target terapinya.

Berdasarkan latar belakang, penelitian mengenai evaluasi ketepatan pemilihan dosis penggunaan obat anti hipertensi perlu dilakukan. Hal ini dilakukan untuk melihat apakah terapi antihipertensi yang digunakan terdapat kasus DRP kategori pemilihan dosis. Selain itu juga untuk mengetahui keefektifan terapi antihipertensi dengan melihat tercapai atau tidaknya target terapi/outcome. Berdasarkan latar belakang yang ada dan belum adanya penelitian serupa di RS Roemani Muhammadiyah Semarang mendorong peneliti untuk melakukan penelitian.

\section{METODE PENELITIAN}

Penelitian yang dilakukan merupakan penelitian noneksperimental. Metode penelitian yang digunakan adalah metode deskriptif analitik dengan menggunakan pendekatan retrospektif. Penelitian dilakukan di bagian rekam medik RS Roemani Muhammadiyah Semarang. Penelitian dilakukan selama bulan Mei 2019. Populasi yang digunakan adalah seluruh pasien hipertensi yang berada di instalasi rawat inap RS Roemani Muhammadiyah Semarang pada periode Januari sampai dengan Desember 2018. Teknik pengambilan sampel yang digunakan adalah purposive sampling, berdasarkan hasil perhitungan diambil sebanyak 79 sampel. Sampel yang ambil harus memenuhi kriteria inklusi dan eksklusi.

Kriteria inklusi yang digunakan, yaitu pasien dengan diagnosis hipertensi, dengan atau tanpa penyakit penyerta, pasien rawat inap periode Januari Desember 2018, mendapat terapi antihipertensi, berusia $\geq 18$ tahun, Memiliki data rekam medik lengkap yang mencakup data pasien dan dan 
data penggunaan obat antihipertensi. Sedangkan kriteria eksklusi yang digunakan, yaitu pasien pulang paksa, meninggal, hamil, terdiagnosa penyakit jantung, penyakit ginjal dan stroke.

\section{HASIL DAN PEMBAHASAN}

\section{Karakteristik Pasien}

a) Jenis Kelamin

Berdasarkan hasil penelitian yang dilakukan ditemukan lebih banyak pasien yang berjenis kelamin perempuan dibandingkan dengan pasien laki-laki. Terdapat sebanyak 54 pasien perempuan $(68,35 \%)$ sedangkan pasien laki-laki berjumlah 25 pasien $(31,65 \%)$. Pada wanita yang sudah menopause, dapat dipengaruhi oleh menurunnya kadar hormon esterogen. Penurunan hormon esterogen tersebut yang mempengaruhi naiknya tekanan darah melalui aktivasi sistem renin-angiotensin (RAS) dan sistem syaraf pusat. Angiotensin-II (A-II) merupakan substrat utama pada RAS, yang merupakan vasokonstriktor poten yang menyebabkan konstriksi pada pembuluh darah (Abramson dan Melvin, 2014).

\begin{tabular}{cccc}
\hline Kelompok Usia & $\begin{array}{c}\text { Rentang Usia } \\
\text { (tahun) }\end{array}$ & Jumlah & $\begin{array}{c}\text { Persentase } \\
(\%)\end{array}$ \\
\hline Remaja & $18-25$ & 3 & 3,80 \\
Dewasa & $26-45$ & 13 & 16,46 \\
Lansia & $46-65$ & 60 & 75,95 \\
Manula & $>65$ & 3 & 3,80 \\
\hline \multicolumn{6}{c}{ Total } & & 97 & 100 \\
\hline \multicolumn{2}{c}{ Berdasarkan } & penelitian & kelompok usia 35- 60 tahun \\
sebelumnya yang & dilakukan & mempunyai resiko 1,99 kali \\
pada populasi dengan rentang & lebih besar menderita hipertensi \\
usia 15-60 tahun. Hasil dari & dibanding dengan kelompok usia \\
penelitian tersebut menyatakan & 15-34 tahun (Pradono et al., \\
bahwa responden & dengan & 2013). Hal ini sejallan dengan
\end{tabular}

Sedangkan pada wanita usia produktif meningkatnya kejadian hipertensi dapat dipengaruhi oleh penggunaan kontrasepsi hormonal atau pil KB. Berdasarkan penelitian sebelumnya, yang dilakukan pada wanita usia subur, diketahui bahwa penggunaan kontrasepsi oral (pil KB) meningkatkan resiko menderita hipertensi. Resiko peningkatan hipertensi tersebut meningkat seiring dengan lamanya penggunaan pil KB (Kaunang et al., 2014; Pangaribuan dan Lolong, 2015).

b) Usia

Pada penelitian ini, presentase pasien kategori usia remaja terdapat sebanyak $3,80 \%$, pada kategori usia dewasa sebanyak $16,46 \%$, pada kategori usia lansia terdapat sebanyak $75,95 \%$, dan pada kategori usia manula terdapat sebanyak $3,80 \%$ (Tabel 1).

\section{Tabel 1. Distribusi}

Karakteristik Pasien

Berdasarkan Usia (Depkes, 2009) 
Enzyme Inhibitor), yang memiliki efek samping berupa batuk kering (Abraham et al., 2015). Selain itu, penggunaan ARB untuk jangka panjang tidak mempengaruhi lipid dan glukosa darah (Nafrialdi, 2007).

b) Penggunaan Antihipertensi Kombinasi

Berdasarkan

golongannya, kombinasi antihipertensi yang paling banyak digunakan adalah kombinasi $\mathrm{ARB}+\mathrm{CCB}$, yaitu sebanyak 59,57\% (Tabel 4). Kombinasi CCB dan ARB tepat karena keduanya bekerja dengan mekanisme yang berbeda untuk menurunkan tekanan darah. Selain itu, kedua kelas antihipertensi tersebut merupakan first line terapi antihipertensi menurut JNC VIII (2014). Kombinasi tersebut juga digunakan untuk mencegah terjadinya diabetes nefropati pada pasien diabetes mellitus dengan hipertensi (Kalra et al., 2010). Penelitian lain juga menyebutkan bahwa terjadinya efek samping udema perifer dan sakit kepala lebih rendah pada penggunaan kombinasi amlodipin dan valsartan (ARB-CCB) dibandingkan dengan penggunaan amlodipin (CCB) sebagai monoterapi (Phillip et al., 2007).

Tabel 4. Distribusi Penggunaan Antihipertensi Kombinasi

\begin{tabular}{|c|c|}
\hline Kelas Antihipertensi & $\begin{array}{c}\text { Persentase } \\
(\%)\end{array}$ \\
\hline $\mathrm{ACEI}+\mathrm{CCB}$ & 2,12 \\
\hline $\mathrm{ARB}+\beta-$ Blocker $+\mathrm{CCB}$ & 19,14 \\
\hline $\begin{array}{c}\mathrm{ARB}+\beta-\text { Blocker }+\mathrm{CCB}+\text { Diuretik } \\
\text { Tiazid }\end{array}$ & 6,38 \\
\hline $\begin{array}{c}\mathrm{ARB}+\beta-\text { Blocker }+\mathrm{CCB}+\text { Agonis } \alpha-2 \\
\text { Sentral }\end{array}$ & 4,26 \\
\hline $\mathrm{ARB}+\mathrm{CCB}$ & 59,57 \\
\hline $\mathrm{ARB}+\mathrm{CCB}+$ Diuretik Tiazid & 4,2 \\
\hline$\beta-$ Blocker $+\mathrm{CCB}$ & 4,2 \\
\hline Jumlah & $\begin{array}{ll}47 & 100 \\
\end{array}$ \\
\hline $\begin{array}{l}\text { Keterangan: } \\
\text { ARB : Angiotensin Receptor } \\
\text { Blocker }\end{array}$ & $\begin{array}{l}\text { tinggi (over dosis), frekuensi } \\
\text { pemberian kurang dan frekuensi } \\
\text { pemberian berlebih. Berdasarkan }\end{array}$ \\
\hline $\begin{array}{l}\text { CCB : Calcium Channel } \\
\text { Blocker } \\
\text { ACEI: Angiotensin Converting } \\
\text { Enzyme Inhibitor }\end{array}$ & $\begin{array}{l}\text { hasil evaluasi yang dilakukan } \\
\text { (Tabel 5), terdapat } 2 \text { kasus yang } \\
\text { menerima terapi antihipertensi } \\
\text { dengan frekuensi berlebih dan }\end{array}$ \\
\hline $\begin{array}{l}\text { aluasi DRPs } \quad \text { Kategori } \\
\text { milihan Dosis }\end{array}$ & $\begin{array}{l}\text { sebanyak } 1 \text { kasus dosis berlebih. } \\
\text { Terdapat sebanyak } 3 \text { kasus DRPs }\end{array}$ \\
\hline $\begin{array}{l}\text { Evaluasi DRPs } \\
\text { milihan dosis dibagi menjadi } \\
\text { berapa poin yaitu dosis terlalu } \\
\text { adah (sub dosis), dosis terlalu }\end{array}$ & $\begin{array}{ll}\text { yang terjadi pada } 2 \text { pasien } & (2,53 \%) \\
\text { dan } 77 \text { pasien }(97,47 \%) & \text { lainnya } \\
\text { sudah menerima terapi } & \text { dengan } \\
\text { dosis yang tepat (Tabel } 6) & \end{array}$ \\
\hline
\end{tabular}


Tabel 5. Distribusi Evaluasi

DRPs Kategori Pemilihan

Dosis

\begin{tabular}{lrc}
\hline \multicolumn{2}{c}{ Evaluasi DRPs } & Jumlah \\
\hline \multirow{2}{*}{ Dosis } & Kurang & - \\
& Berlebih & 1 \\
\hline \multirow{2}{*}{ Frekuensi } & Kurang & - \\
& Berlebih & 2 \\
\hline \multicolumn{2}{c}{ Jumlah Kasus } & $\mathbf{3}$ \\
\hline
\end{tabular}

Tabel 6. Distribusi Ketepatan

Pemilihan Dosis

\begin{tabular}{|c|c|c|}
\hline Ketepatan Pemilihan Dosis & Jumlah & Persentase (\%) \\
\hline Tepat & 77 & 97,47 \\
\hline Tidak Tepat & 2 & 2,53 \\
\hline Total & 79 & 100 \\
\hline $\begin{array}{l}\text { Pada terapi hipertensi dosis } \\
\text { merupakan hal yang penting dalam } \\
\text { menentukan hasil terapi. Dalam } \\
\text { pemberian dosis juga harus } \\
\text { memperhatikan kondisi pasien }\end{array}$ & & $\begin{array}{l}\text { respon yang beragam dan tidak } \\
\text { selalu bisa diperkirakan (Joenoes, } \\
\text { 2001). Selain itu setiap obat juga } \\
\text { memiliki profil yang berbeda yang } \\
\text { dapat mempengaruhi efek terapi } \\
\text { obat. }\end{array}$ \\
\hline
\end{tabular}

seperti usia, berat badan, jenis kelamin, toleransi, sensitivitas, dll.

Faktor ini sangatlah kompleks, karena setiap individual memiliki

\begin{tabular}{|c|c|c|c|c|c|}
\hline $\begin{array}{l}\text { No. } \\
\text { Kasus }\end{array}$ & $\begin{array}{c}\text { Terapi } \\
\text { Hipertensi }\end{array}$ & $\begin{array}{c}\text { Dosis } \\
\text { Standar }\end{array}$ & Tepat & $\begin{array}{l}\text { Tidak } \\
\text { Tepat }\end{array}$ & Keterangan \\
\hline 30 & $\begin{array}{l}\text { Nifedipin } 1 \text { x } 30 \\
\text { mg } \\
\text { Bisoprolol } 1 \text { × } 5 \\
\text { mg } \\
\text { HCT } 3 \times 25 \text { mg }\end{array}$ & $\begin{array}{c}30-180 \mathrm{mg} / \\
24 \mathrm{jam} \\
2,5-20 \mathrm{mg} / \\
24 \mathrm{jam} \\
12,5-50 \mathrm{mg} / \\
12-24 \mathrm{jam}\end{array}$ & $\sqrt{ }$ & $\sqrt{ }$ & $\begin{array}{l}\text { Frekuensi dan } \\
\text { Dosis pemberian } \\
\text { perhari HCT } \\
\text { berlebih }\end{array}$ \\
\hline 47 & $\begin{array}{c}\text { Amlodipin } 2 \times 5 \\
\mathrm{mg}\end{array}$ & $\begin{array}{c}5-10 \mathrm{mg} / 24 \\
\text { jam }\end{array}$ & & $\sqrt{ }$ & $\begin{array}{l}\text { Frekuensi } \\
\text { pemberian } \\
\text { Amlodipin } \\
\text { berlebih }\end{array}$ \\
\hline
\end{tabular}

Terjadinya DRPs frekuensi berlebih terjadi pada pasien yang menerima Amlodipin 2 x $5 \mathrm{mg}$ (Tabel 7). Berdasarkan dosis yang direkomendasikan pada DIH (2018) frekuensi penggunaan Amlodipin sebagai antihipertensi adalah satu kali sehari (once daily dose), yaitu $5 \mathrm{mg} /$ hari sebagai dosis awal dan dapat ditingkatkan menjadi 10 $\mathrm{mg} /$ hari jika dibutuhkan. Pemberian
Tabel 7 Evaluasi DRPs Kategori Pemilihan Dosis

amlodipin 2 x $5 \mathrm{mg}$ sebenarnya tidak melebihi dosis maksimal yang ditetapkan, namun dinilai tidak efektif dan tidak memberikan manfaat tambahan. Namun, jika dilihat tekanan darah pasien saat pulang (No. Kasus 47), pasien tersebut sudah tercapai target terapinya. Hasil tersebut bertentangan dengan penelitian Miyoshi et al. (2013) yang menyatakan bahwa pemberian 
Amlodipin dalam dua dosis terbagi tidak berhubungan dengan meningkatnya konsentrasi amlodipin didalam plasma, tidak mengurangi arterial stiffness, dan tidak meningkatkan kontrol terhadap tekanan darah dalam waktu 24 jam pada pasien dengan hipertensi esensial.

Sedangkan

pada pemberian HCT berdasarkan dosis yang direkomendasikan dalam DIH (2018), pemberian HCT sebagai antihipertensi adalah 12,5-50 $\mathrm{mg}$ /hari, sehingga pada kasus ini pemberian HCT 3 x $25 \mathrm{mg}$ terlalu banyak jika dilihat dari frekuensi pemberian maupun dosis perhari. Dalam penelitian sebelumnya menyatakan, pemberian HCT dosis rendah (12,5-25 mg/hari) atau dosis tinggi $(\geq 50 \mathrm{mg} /$ hari $)$ dapat menurunkan tekanan darah pada derajat yang sama, dan memiliki keuntungan dalam mengurangi resiko stroke, gagal jantung kongestif, dan kematian. Namun, pada pemberian HCT dosis rendah yang dapat secara signifikan menurunkan kejadian jantung koroner (CHD). Sehingga pemberian HCT dosis rendah (12$25 \mathrm{mg} / \mathrm{hari}$ ) dinilai lebih optimal (Salvetti dan Ghiadoni, 2006).

\section{Keefektifan}

Terapi

\section{Antihipertensi}

Pada penelitian ini dalam
menilai keefektifan
antihipertensi, digunakan tekanan
darah pasien pada hari terakhir

\begin{tabular}{|c|c|c|}
\hline $\begin{array}{c}\text { Pemilihan } \\
\text { Dosis }\end{array}$ & Tercapai & $\begin{array}{c}\text { Persenta } \\
(\%)\end{array}$ \\
\hline Tepat & 54 & 68,35 \\
\hline Tidak Tepat & $1^{\mathrm{a}}$ & 1,27 \\
\hline $\begin{array}{c}\text { Jumlah } \\
(n=79)\end{array}$ & \multicolumn{2}{|c|}{55} \\
\hline
\end{tabular}

Keterangan: perawatan (saat pulang) yang tercatat pada data rekam medik pasien, kemudian dibandingkan dengan target tekanan darah menurut JNC VIII. Tujuan dari terapi hipertensi adalah terkontrolnya tekanan darah sehingga tidak menyebabkan terjadinya keparahan penyakit yang dapat terjadi. Target tekanan darah sesuai dengan rekomendasi JNC VIII adalah $<140 /<90 \mathrm{mmHg}$ untuk populasi umum $18-60$ tahun, $\geq 18$ tahun dengan CKD dan $\geq 18$ tahun dengan DM. Sedangkan untuk populasi umum $\geq 60$ tahun target tekanan darah yang direkomendasikan adalah $<150 /<90$ $\mathrm{mmHg}$.

Berdasarkan hasil evaluasi DRPs kategori pemilihan dosis dan keefektifan terapi antihipertensi (Tabel 8) terdapat sebanyak 54 pasien $(68,35 \%)$ yang pemilihan dosis sudah tepat dan target terapinya tercapai dan sebanyak 23 pasien $(29,11 \%)$ pemilihan dosis sudah tepat namun target terapi belum tercapai. Sedangkan sebanyak 1 pasien $(1,27 \%)$ yang pemilihan dosisnya belum tepat (terdapat DRPs) dan target terapinya tercapai dan sebanyak 1 pasien $(1,27 \%)$ yang pemilihan dosisnya belum tepat dan target terapinya tidak tercapai.

\section{Tabel 8 Distribusi Evaluasi DRPs Kategori Pemilihan Dosis Dan Keefektifan Terapi Antihipertensi}


b : no. kasus 30

Diantara pasien tersebut terdapat 1 pasien $(1,27 \%)$ yang terdapat DRP pada terapinya, yaitu kategori frekuensi berlebih (Tabel 1.8). Terjadinya DRP tersebut dapat menyebabkan terapi tidak efektif sehingga dapat mempengaruhi outcome terapi pasien, yaitu dengan tidak tercapainya target tekanan darah. Pada pasien lainnya, tidak tercapainya target terapi dapat disebabkan adanya faktor lain atau adanya DRPs kategori lainnya. Selain itu, terdapat juga pasien yang target terapinya sudah tercapai namun terdapat DRP dalam terapinya (Tabel 1.8), yaitu kategori frekuensi berlebih sebanyak 1 pasien $(1,27 \%)$. Hal tersebut dapat saja terjadi, karena tercapainya outcome / target terapi tidak hanya dipengaruhi oleh ketepatan pemilihan dosis saja dan dapat disebabkan oleh adanya DRPs kategori lainnya.

Selain karena adanya DRPs pada terapi, terdapat faktor lain yang dapat mempengaruhi naik dan turunnya tekanan darah. Adanya penyakit penyerta lain yang diderita, usia pasien, jenis kelamin, posisi tubuh, berat badan berlebih (obesitas), kondisi stress atau keadaan psikologis, dan pola hidup sebelumnya yang tidak sehat dapat mempengaruhi penurunan tekanan darah sesuai dengan target terapi (Marhaendra, 2016).

\section{KESIMPULAN}

Berdasarkan hasil penelitian evaluasi Drug Related Problems (DRPs) kategori pemilihan dosis pada pasien hipertensi di instalasi rawat inap RS Roemani Muhammadiyah Semarang Periode Januari-Desember 2018, dapat diambil kesimpulan:
1. Terdapat sebanyak 32 pasien $(40,51 \%)$ menggunakan terapi antihipertensi tunggal dan sebanyak 47 pasien $(59,49 \%)$ menggunakan terapi antihipertensi kombinasi.

2. Kejadian DRPs kategori pemilihan dosis sebanyak 3 kasus yang terjadi pada 2 pasien $(2,53 \%)$. DRPs yang terjadi, yaitu pada kategori frekuensi berlebih, yaitu sebanyak 2 kasus dan dosis berlebih. Sedangkan 77 pasien lainnya $(97,47 \%)$ sudah menerima terapi dengan dosis dan frekuensi pemberian yang tepat sesuai yang tercantum pada DIH 2018.

3. Keefektifan terapi antihipertensi pada pasien rawat inap RS Roemani Muhammadiyah Semarang sebesar $69,62 \%$ (55 pasien).yang dilihat dari tercapainya target terapi sesuai JNC VIII.

\section{DAFTAR PUSTAKA}

Abraham, H. M. A., White, C. M., \& White, W. B. (2015). "The comparative efficacy and safety of the angiotensin receptor blockers in the management of hypertension and other cardiovascular diseases". Drug safety, 38(1), 33-54.

Abramson, B. L. Dan Melvin, R. G., (2014) "Cardiovascular Risk in Women: Focus on Hypertension" Canadian Journal of Cardiology, 30, 2014. University of Toronto, Cardiac Prevention Centre and Women's Cardiovascular Health, St Michael's Hospital, Toronto, Canada.

Aziza, L., (2007) "Peran Antagonis Kalsium dalam Penatalaksanaan Hipertensi” Jakarta. Majalah Kedokteran Indonesia, 259-264. 
Cipolle, R.J, Strand, L.M. \& Morley, P.C. (1998) Pharmaceutical Care Practice. New York: Mc Graw Hill Company.

Ganiswara S. (2006). Farmakologi dan Terapi. Edisi 6. EGC. Jakarta.

Indonesia, Departemen Kesehatan (2009) Sistem Kesehatan Nasional Tahun 2009. Jakarta.

Indonesia, Dinas Kesehatan (2017) Profil Kesehatan Profinsi Jawa Tengah Tahun 2017. Semarang.

James, P.A., Oparil S., Carter L.B., Cushman, W.C., DennisonHimmelfarb, C., Handler, J., et al., (2014), 2014 Evidence-based Guideline Or the Manegement Of High Blood Pressure In Adults Report Form The Panel Members Appointed To The Eighth Joint National Committee (JNC 8). USA.

Joenoes, N. Z. (2004) Ars Prescribendi Resep yang Rasional Edisi II. Surabaya: Airlangga University Press.

Kalra, S., Kalra, B., \& Agrawal, N. (2010). "Combination therapy in hypertension: An update". Diabetology \& metabolic syndrome, 2(1), 44.

Kaunang, S. S., Kepel, B. J., Malonda, N. S.H., (2014). "Hubungan Antara Penggunaan Kontrasepsi Pil Dengan Kejadian Hipertensi Pada Wanita Usia Subur Di Wilayah Kerja Puskesmas Bahu Kota Manado" Fakultas Kesehatan Masyarakat dan Fakultas Kedokteran Universitas Sam Ratulangi, Manado.
Lacy, C. F., Amstrong, L. L., Goldman, P., dan Lance, L. L., (2018) "Drug Information Handbook $26^{\text {th }}$ Edition "; USA: Lexicomp

Marhaendra, Y. A. (2016) "Pengaruh Letak Tensi Meter Terhadap Hasil Pengukuran Tekanan Darah. Karya Tulis Ilmiah. Universitas Diponegoro, Semarang.

Miyoshi, K. I., Okura, T., Nagao, T., Masanori, J., Irita, J., \& Higaki, J. (2013). "Effects of Dividing Amlodipine Daily Doses on Trough Drug Concentrations and Blood Pressure Control Over a 24-Hour Period" Clinical therapeutics, 35(9), 1418-1422.

Nafrialdi. (2007) Antihipertensi dalam Gunawan, S.G.,Setianudi, R., Nafrialdi, Elysabeth,. Editor. Farmakologi dan Terapi (Edisi Kelima). Jakarta: Gaya Baru.

Pangaribuan, L., \& Lolong, D. B. (2015) "Hubungan penggunaan kontrasepsi pil dengan kejadian hipertensi pada wanita usia 1549 tahun di Indonesia tahun 2013 (analisis data riskesdas 2013)" Media Penelitian dan Pengembangan Kesehatan, 25(2), 89-96.

PCNE. (2018) Classification for Drug Related Problems V8.03 Pharmaceutical Care. Zuidlaren.

Philipp, T., Smith, T. R., Glazer, R., Wernsing, M., Yen, J., Jin, J., \& Pospiech, R. (2007). "Two multicenter, 8-week, randomized, double-blind, placebo-controlled, parallel-group studies evaluating the efficacy and tolerability of amlodipine and valsartan in 
combination and as monotherapy in adult patients with mild to moderate essential hypertension" Clinical therapeutics, 29(4), 563-580

Pradono, J., Indrawati, L., \& Murnawan, T. (2013). "Permasalahan dan Faktor Risiko yang Berhubungan dengan Terjadinya Hipertensi di Kabupaten Bogor Prov. Jawa Barat" Buletin Penelitian Kesehatan, 41(2 Jun), 61-71.

Rahajeng, E., \& Tuminah, S. (2009). "Prevalensi hipertensi dan determinannya di Indonesia" Majalah Kedokteran Indonesia, 59(12), 580-587.

Salvetti, A., \& Ghiadoni, L. (2006). "Thiazide diuretics in the treatment of hypertension: an update" Journal of the American Society of Nephrology, 17(4 suppl 2), S25S29.

Susilowati, A., \& Risnawati, C. (2017). "Gambaran Pola Pengobatan Hipertensi Di Puskesmas Berbah Sleman Yogyakarta Bulan Januari 2017" Jurnal Kefarmasian Akfarindo, 25-32.

Tyashapsari, MM W.R. dan Zulkarnain, A.K. (2012) Penggunaan Obat pada Pasien Hipertensi di Instalasi Rawat Inap Rumah Sakit Umum Pusat Dr. Kariadi Semarang. Majalah Farmaseutik, Pharmaceutics Journal Vol. 8, No.2. Yogyakarta. 